\title{
Recruitment limitation of forest communities in a degraded Mediterranean landscape
}

\author{
Mendoza, Irene $^{1 *}$; Gómez-Aparicio, Lorena ${ }^{2}$; Zamora, Regino ${ }^{1,3} \&$ Matías, Luis ${ }^{1,4}$ \\ ${ }^{1}$ Department of Ecology, Terrestrial Ecology Research Group, University of Granada, Av. Fuentenueva s/n, E-18071 \\ Granada, Spain; \\ ${ }^{2}$ Instituto de Recursos Naturales y Agrobiología (IRNASE, CSIC), PO Box 1052, 41080 Seville, Spain; \\ E-mail: lorenag@irnase.csic.es; ${ }^{3}$ E-mail rzamora@ugr.es; ${ }^{4}$ E-maillmatias@ugr.es; \\ *Corresponding author; Fax: +349582 46166; E-mail imendoza@ugr.es
}

\begin{abstract}
Question: How does habitat degradation affect recruitment limitation and its components (seed limitation versus establishment limitation) of woody plant communities in a Mediterranean landscape?
\end{abstract}

Location: 1600-1900 m a.s.l. in the Sierra Nevada National Park, southern Spain. The landscape is a mosaic composed of native forest and two degraded landscape units: reforestation stands and shrubland.

Methods: We evaluated fruit production, seed rain, seedling emergence and seedling survival in two consecutive years with contrasting rainfall patterns. Seed and seedling data were used to calculate values of seed and establishment limitation.

Results: In general, the woody community was both severely seed- and establishment-limited. Species were less seed-limited in the landscape units with higher adult density (i.e. shrub species in shrubland, Pinus spp. in reforestation stands). In contrast, degradation did not exacerbate establishment limitation, which was severe in all landscape units. This general pattern was modulated by the biogeographical distribution, dispersal type, and life form of the species. Boreo-alpine species were more limited in establishment than species with a typical Mediterranean distribution. Zoochorous species were less seed-limited in the landscape units preferred by dispersers (i.e. native forest). Tree species were more establishmentlimited than shrub species, irrespective of the landscape unit. Seed limitation, and especially establishment limitation, varied among years, with establishment being almost nil in the very dry year.

Conclusion: In the case of Mediterranean landscapes, when degradation from human impact involves a reduction in the adult abundance of the woody plant community (trees and shrubs), seed limitation increases, although establishment limitation is generally high in all landscape units, especially for boreo-alpine species. Con- servation and restoration strategies should take into account our results showing that tree species were unable to recruit in an extremely dry year, because more aridity is expected under a climatic change scenario in Mediterranean ecosystems.

Keywords: Acer opalus subsp. granatense; Land-use change; Pinus sylvestris; Regeneration dynamics; Seed dispersal; Sorbus aria; Taxus baccata.

Nomenclature: Castroviejo et al. 1986; Valdés et al. 1987; Blanca et al. 2002.

\section{Introduction}

Human impact is so widespread throughout the Earth's ecosystems that most habitats undergo some form of degradation (Sanderson et al. 2002). Under this general context of habitat degradation, it is crucial to understand recruitment limitation hampering the natural capacity of plant populations to recover (Jordano et al. 2004). Studies addressing recruitment limitation have normally examined wellconserved habitats, i.e. tropical (Dalling et al. 2002; Muller-Landau et al. 2002; Svenning \& Wright 2005), temperate (Schupp \& Fuentes 1995; Clark et al. 1998), boreal (Eriksson \& Ehrlén 1992) or, more rarely, Mediterranean (Jordano \& Herrera 1995; Hampe \& Arroyo 2002; Rey et al. 2006) habitats. While these studies provide a general understanding of recruitment limitation when human impact is relatively low, studies focusing on habitat degradation are rare, and generally centred on savannah-type ecosystems (e.g. Plieninger et al. 2003; Pulido \& Díaz 2005).

The standard approach to analyse recruitment limitation includes two components (Eriksson \& Ehrlén 1992; Clark et al. 1998, 1999; Nathan \& 
Muller-Landau 2000; Muller-Landau et al. 2002): (1) seed limitation, defined as the failure of seeds to arrive at all suitable sites, and (2) establishment limitation, defined as the reduced suitability of microsites for successful seedling establishment. Seed limitation can result from a low density of adults, reduced adult fertility and limited seed dispersal (Clark et al. 1998). Establishment limitation may derive from low seed survival and germination, as well as the failure of seedlings to emerge and to survive (Clark et al. 1998). Habitat degradation might affect seed limitation by lowering the density and fecundity of parent trees (Ghazoul et al. 1998) and by altering dispersal patterns of frugivores (Da Silva et al. 1996). Analogously, human impact could translate into establishment limitation by altering physico-chemical factors (e.g. lower amount of soil moisture, nutrients or light availability) and biotic factors (e.g. higher number of post-dispersal seed and seedling predators, pathogens or competitors) that reduce microsite suitability for seedling emergence and survival.

Mediterranean ecosystems offer ample opportunity to study the magnitude of recruitment limitation in degraded habitats, given that millennia of human presence have disturbed $99.8 \%$ of all natural areas (Blondel 2006). Native forests have almost disappeared due to massive timber cutting, fires, cultivation or herbivore pressure (Conacher \& Sala 1998). The result is a patch mosaic of native vegetation and degraded habitats such as reforestation stands and shrublands, where plant species vary in their biogeographical distribution (boreo-alpine, Mediterranean or European-North African), dispersal system (zoochorous versus non-zoochorous) and life form (trees versus shrubs).

The objective of this study is to determine whether recruitment limitation in the entire woody plant community of a Mediterranean mountain is affected at the landscape scale by habitat degradation resulting from different types of human impact. Specifically, we seek to determine whether the relative importance of the two components of recruitment limitation (seed versus establishment limitation) depends on: (1) type of human impact exerted in each landscape unit; (2) biogeographical distribution of the woody species (Boreal-Alpine, Mediterranean or European-North African; (3) dispersal system (zoochorous versus non-zoochorous); and/or (4) life form (tree versus shrub). Previous studies analysing the influence of habitat degradation on recruitment limitation have focused on only one species (e.g. Traveset et al. 2003; Pulido \& Díaz 2005; Acácio et al. 2007). To date, studies compar- ing the relative importance of the two components of recruitment limitation (seed limitation versus establishment limitation) using the community approach are rare, except for tropical forests (see Dalling et al. 2002; Muller-Landau et al. 2002).

\section{Material and Methods}

\section{Study area}

The study was conducted from 2003 to 2005 at Trevenque, in the Sierra Nevada National Park $\left(37^{\circ} 05^{\prime} \mathrm{N}, 3^{\circ} 28^{\prime} \mathrm{W}\right.$, Granada, SE, Spain). This mountain area has a continental Mediterranean climate, with cold winters and hot, dry summers. The study years had contrasting rainfall patterns: 2004 was considered as a normal year in terms of annual rainfall $\left(750 \mathrm{~mm} \mathrm{yr}^{-1}\right)$, while $2005\left(394 \mathrm{~mm} \mathrm{yr}^{-1}\right)$ was the driest year of a 46-year series (1958-2005).

As result of a long history of land use, the study area located between 1600 and $1900 \mathrm{~m}$ a.s.l. is a mosaic composed of patches of three different landscape units: (1) native forest [dominated by Pinus sylvestris mixed with other trees such Acer opalus subsp. granatense (hereafter A. granatense), Sorbus aria or Taxus baccata as well as a dense shrubby understorey]; (2) reforestation stands (planted in the 1950s and dominated by $P$. sylvestris and $P$. nigra); and (3) post-fire shrublands (originating after a fire in 1983).

\section{Sampling design}

We selected three plots in native forest and shrubland, and nine plots in reforestation stands ( $n=15$ plots in total). Plots were delimited by natural boundaries and their area varied from 0.16 to 0.93 ha, with a mean size of 0.53 ha (determined by GIS). In all landscape units, we measured seed rain and monitored seedlings at fixed points, hereafter called sampling stations. The total number of sampling stations in the study was 495 (180 in native forest and shrubland, 135 in reforestation stands).

In each of the 15 plots, we determined the abundance of all reproductive individuals of tree and shrub species. In the case of tree species, we counted all individuals present in each plot. Due to the high shrub density, shrub adults were sampled using ten transects of $25 \mathrm{~m} \times 2 \mathrm{~m}(n=150)$ randomly distributed in each plot $\left(7500 \mathrm{~m}^{2}\right.$ in total $)$.

\section{Fruit production}

Fruit production, which normally starts in September and finishes in February of the following 
year, was estimated for tree species and for the most abundant fleshy-fruited shrubs (Berberis vulgaris, Crataegus monogyna, Juniperus communis, Prunus ramburii, Lonicera xylosteum and Rosa spp.) by sampling 15 individuals of each species per plot. Fruit production was visually estimated using the fruit abundance index (FAI), which followed a logarithmic scale: $0=$ no fruits, $1=1-10$ fruits, $2=11-100$ fruits, $3=101-1000$ fruits, $4=1001$ 10000 fruits, and $5=>10000$ fruits (see Saracco et al. 2004 for similar methods)

\section{Seed rain}

We quantified seed rain using seed traps from October 2003 to April 2005 (two complete dispersal seasons). A pair of seed traps was located at each sampling station ( $n=990$ seed traps). Because wild boar intensively root up the soil under pine trees, we used two different models of seed trap: under pine trees, we used pots nailed to trees at $160 \mathrm{~cm}$ (and therefore out of reach of wild boar), and for the remaining microhabitats, we used aluminium trays nailed to the ground. Sampling surfaces of both types of trap were roughly similar $\left(\approx 0.04 \mathrm{~m}^{2}\right)$. Both kinds of trap were protected against post-dispersal seed predation by a wire mesh of $1-\mathrm{cm}$ grid size. For each species, the number of seeds per mature fruit was estimated or directly counted.

\section{Seedling emergence and survival}

Seedling emergence and survival were monitored using two $1-\mathrm{m}^{2}$ quadrats per sampling station, located close to each pair of seed traps. Seedling emergence was recorded once per year at the beginning of spring (May-June). As we found no significant permanent soil seed bank for the woody species in the study area (Mendoza 2008), we considered all the seedlings to have originated from the seed rain of that year. Survival of seedlings was monitored once at the end of summer (October). We monitored second-year survival for seedlings that had emerged in 2004 and that were still alive at the end of that summer.

\section{Data analyses}

For adult density, we divided the number of individuals in each plot by the plot area. For seed density, we divided the total number of seeds in each plot by the summed area of seed traps. In the case of seedlings, total number per plot was divided by the summed area of the quadrats. Density values were compared between landscape units for each species and year using Generalized Linear Models, with a Poisson distribution for the response variable and a logit link.

The variation in fruit production between years and landscape units was compared using Generalized Models, with an ordinal multinomial distribution for the response variable (FAI) and a logit link.

\section{Components of recruitment limitation}

Although the most straightforward way to assess recruitment limitation is through seed addition experiments (Turnbull et al. 2000; Münzbergová \& Herben 2005), an experimental approach is impractical at large spatial scales and thus also at the woody community scale. Therefore, we adopted an observational approach that has been successfully used in other studies (e.g. Dalling et al. 2002; Muller-Landau et al. 2002; Gómez-Aparicio et al. 2007). The two components of recruitment limitation (seed and establishment limitation) were calculated separately for each study year, landscape unit and tree species (except for the genus Quercus, because seed traps were not suitable for sampling its seed rain; Gómez 2003). For shrubs, we considered the dispersal mode to be more relevant to community structure than species identity; therefore, we performed separate analyses for summed data of fleshyfruited (zoochorous dispersal) or dry-fruited (nonzoochorous) species.

Recruitment limitation was calculated following the methodology of Nathan \& Muller-Landau (2000) and Muller-Landau et al. (2002). Fundamental seed limitation was calculated as the proportion of sampling stations not receiving seeds (as observed from the seed traps). Realized establishment limitation was calculated as the proportion of sampling stations receiving seeds where seedlings did not establish. We divided establishment limitation into two components: (1) emergence limitation, defined as the proportion of sampling stations receiving seeds where seedling emergence did not occur, and (2) survival limitation, defined as the proportion of sampling stations where seedlings emerged but where they did not survive the first summer. As a proportion, the values of the components of recruitment limitation ranged from 0 (no limitation) to 1 (maximum limitation). Differences between landscape units for limitation values were compared using Generalized Linear Models, with a binomial distribution for the response variable and a logit link. 
Values are given throughout this paper as mean \pm standard deviation, except for FAI index, which represents the median. All analyses were made using specific codes written for $\mathrm{R} 2.4$.1 software (R Development Core Team 2006).

\section{Results}

Composition and abundance of tree and shrub adults

Sampled adults belonged to 36 species: five trees, 20 fleshy-fruited shrubs dispersed by animals, and nine dry-fruited shrubs with ballistic dispersal (see Appendix S1 for the full list of species). Among landscape units, native forest showed intermediate densities of trees and shrubs, reforestation stands showed the highest density of trees and the lowest of shrubs, while shrubland showed the lowest density of trees and the highest of shrubs (Table 1).

The canopy of the three landscape unit types was dominated by $P$. sylvestris, but density was intermediate in native forest, very high in reforestation stands, and very low in shrubland (LR $\chi^{2}=$ 1488.681; $d f=2 ; P<0.001$; Table 1). The second most common species of the canopy, $P$. nigra, also had higher density in reforestation stands than in shrubland (LR $\chi^{2}=199.1308 ; d f=1 ; P<0.001$ ), whereas it was absent in native forest. The other tree species had low densities and were confined to one type of landscape unit ( $T$. baccata and A. granatense in native forest; $S$. aria in reforestation stands). The highest densities of fleshy-fruited shrubs (LR $\left.\chi^{2}=906.23 ; d f=2 ; P<0.001\right)$ and of dry-fruited shrubs (LR $\left.\chi^{2}=1411.35 ; d f=1 ; P<0.001\right)$ were found in shrubland (Table 1). However, in the native forest and reforestation stands, the understorey was mainly composed of fleshy-fruited shrubs.

\section{Fruit production}

Fruit production was significantly higher in 2004 than in 2005 (LR $\chi^{2}=42.33 ; d f=1 ; P<0.001$; all species pooled). All species had a median fruit abundance index (FAI) $>1$ in both study years, except $P$. sylvestris, $B$. hispanica and $P$. ramburii in 2005, and $P$. nigra in both years (Table 2). Fruit production significantly differed among landscape units, following the same pattern in both study years $\left(\right.$ LR $\chi^{2}=56.40 ; d f=2 ; P<0.0001$ in 2004; LR $\chi^{2}=178.73 ; d f=2 ; P<0.0001$ in 2005; all species pooled): shrubland $>$ native $>$ reforestation stands. 
Table 2. Mean \pm standard values of FAI (0-5) for each studied species in the 2 study years. We included only the landscape units where adults were present.

\begin{tabular}{|c|c|c|c|}
\hline Species & Landscape unit & FAI 2004 & FAI 2005 \\
\hline \multicolumn{4}{|l|}{ Trees } \\
\hline \multirow[t]{2}{*}{ P. sylvestris } & Native & $2.04 \pm 1.22$ & $1.60 \pm 1.14$ \\
\hline & Reforestation & $0.86 \pm 0.90$ & $0.47 \pm 0.68$ \\
\hline P. nigra & Reforestation & $0.11 \pm 0.32$ & $0.09 \pm 0.29$ \\
\hline \multicolumn{4}{|c|}{ Fleshy-fruited shrubs } \\
\hline B. hispanica & Native & $3.03 \pm 1.39$ & $0.03 \pm 0.18$ \\
\hline \multirow[t]{2}{*}{ C. monogyna. } & Native & $1.47 \pm 0.92$ & $2.47 \pm 1.06$ \\
\hline & Shrubland & $2.93 \pm 1.11$ & $3.22 \pm 0.95$ \\
\hline J. communis & Native & $1.66 \pm 1.29$ & $1.93 \pm 1.46$ \\
\hline L. xylosteum & Native & $2.54 \pm 1.22$ & $1.64 \pm 1.04$ \\
\hline P. ramburii & Shrubland & $2.98 \pm 1.10$ & $0.31 \pm 0.47$ \\
\hline
\end{tabular}

\section{Seed limitation}

A total of 14391 seeds were collected during the 2 study years: 5678 seeds of trees, 6070 of fleshyfruited shrubs and 2643 of dry-fruited shrubs. With all tree species pooled, seed limitation significantly varied between landscape units and followed the same pattern during both study years $\left(\chi^{2}=23.60\right.$ in 2004; $\chi^{2}=23.93$ in 2005; $\left.d f=2 ; P<0.0001\right)$ : reforestation stands $<$ native forest $<$ shrubland (Fig. 1). For shrub species, seed limitation followed the opposite pattern, of trees species in the degraded landscape units $\left(\chi^{2}=36.68\right.$ in $2004 ; \chi^{2}=88.32$ in 2005; $d f=2 ; P<0.0001$; Fig. 1). Accordingly, seed density of tree species (LR $\chi^{2}=917.60$ in 2004; LR $\chi^{2}=1516.40$ in 2005; $d f=2 ; P<0.001$; Appendix S2) and of shrub species (LR $\chi^{2}=7257.64$ in 2004; LR $\chi^{2}=7777.102$ in $\left.2005 ; d f=2 ; P<0.001\right)$ significantly differed between landscape units in both study years.

Seed limitation of the dominant species of the canopy, $P$. sylvestris, significantly differed between landscape units $\left(\chi^{2}=36.69\right.$ in $2004 ; \chi^{2}=88.33$ in 2005; $d f=2 ; P<0.0001)$ and followed the same pattern in both study years: reforestation stand$\mathrm{s}<$ native forest $<$ shrubland (Fig. 1). For the rest of the tree species, seed limitation was very high in all landscape units $(>0.75$; Fig. 1$)$, with the exception of $P$. nigra in reforestation stands in 2004 $(0.61 \pm 0.21)$. Seed limitation significantly differed between landscape units for fleshy-fruited shrubs $\left(\chi^{2}=33.56\right.$ in $2004 ; \chi^{2}=43.66$ in $2005 ; d f=2$; $P<0.0001)$ with the same pattern in both years: native forest $<$ shrubland $<$ reforestation stands (Fig. 1). Dry-fruited shrubs had significantly lower values of seed limitation in shrubland than in the other two landscape units $\left(\chi^{2}=46.98\right.$ in 2004; $\chi^{2}=93.64$ in 2005; $\left.d f=2 ; P<0.0001\right)$.

\section{Establishment limitation}

A total of 2059 seedlings were sampled during the 2 study years: 958 were seedlings of trees, 1003 of fleshy-fruited shrubs and 98 of dry-fruited shrubs. With all tree species pooled, establishment limitation was above 0.8 (Fig. 1) in all landscape units in 2004 (normal year), whereas it was complete in 2005 (very dry year). Accordingly, the density of tree seedlings established after the first summer was very low in all landscape units in 2004 and nil in 2005 (Appendix S2). Shrub species had significantly lower establishment limitation in shrubland and reforestation stands than in native forest in 2004 $\left(\chi^{2}=8.68 ; d f=2 ; P<0.015\right.$; Fig. 1$)$, but values were far higher in $2005(>0.9)$ in all landscape units. The density of shrub seedlings that established after the first summer was much higher in 2004 than in 2005 (Appendix S2). Also, more shrub than tree seedlings survived the second summer (Appendix S2).

In 2004, recruitment of tree and shrub species was more limited in survival than emergence in reforestation stands, whereas the opposite pattern appeared in shrubland (Table 3). In 2005, emergence and survival limitation were very high (one or close to one) in all cases except for survival limitation of shrub species in shrubland (0.36).

The main component of the tree canopy, $P$. sylvestris, showed strong establishment limitation in all landscape units and years (non-significant differences). Such limitation was due to survival rather than to emergence (values of survival limitation close to one; Table 3). P. nigra and T. baccata completely collapsed in terms of recruitment, as no emerged seedlings were found in either of the 2 study years. Nevertheless, $S$. aria and A. opalus subsp. granatense showed strong establishment limitation in both study years; these two species were the least limited of trees in 2004 (particularly $S$. aria in reforestation stands, and $A$. opalus subsp. granatense in native forest and shrubland (Fig. 1).

Fleshy-fruited shrub species significantly differed in establishment limitation between landscape units in $2004\left(\chi^{2}=11.84 ; d f=2 ; \quad P=0.0027\right)$, whereas values were close to one in the very dry year of 2005 (Fig. 1). Fleshy-fruited shrubs were the only species that recruited some seedlings in 2005, most of them appearing in shrubland.

\section{Discussion}

Our results clearly indicate that the entire woody community that was studied is substantially 

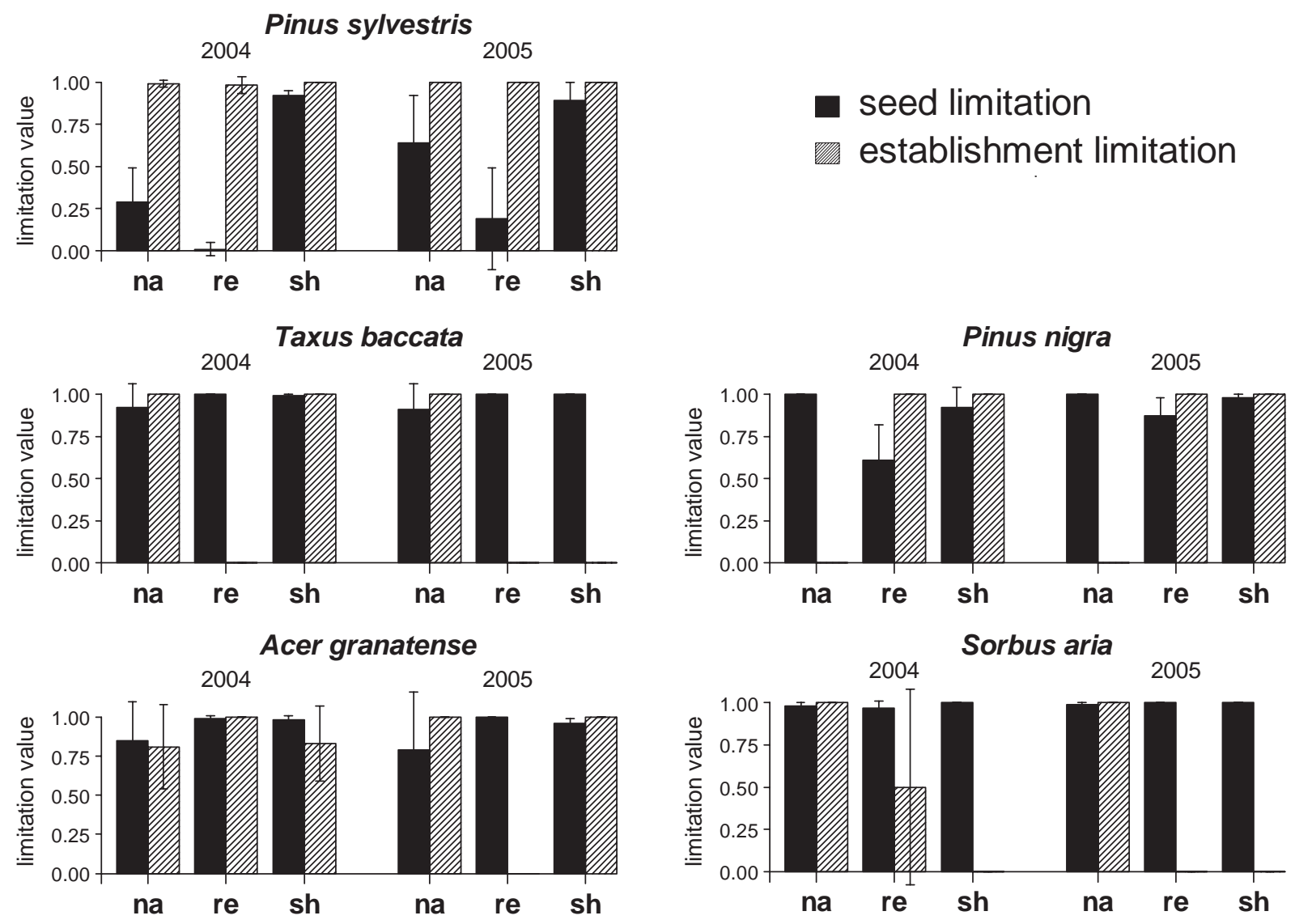

Fleshy-fruited shrubs
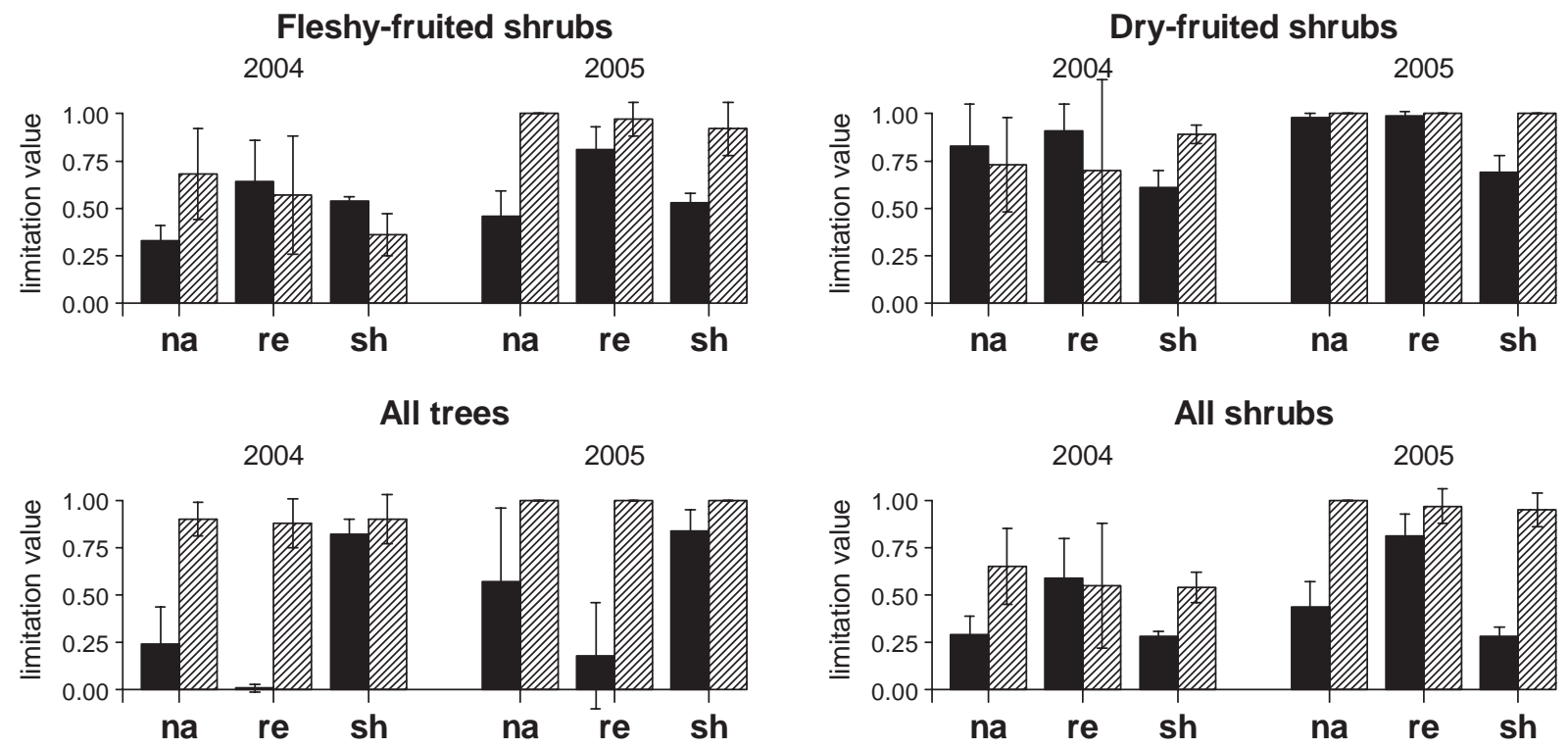

Fig. 1. Seed and establishment limitations for each studied species or functional group in each landscape unit (na, native; re, reforestation stands; sh, shrubland). The first three groups in the columns in each graph represent limitation values in 2004 (normal year) and the last three are for 2005 (dry year).

recruitment-limited, even the least degraded landscape unit (native forest). The type of habitat degradation determined the composition and abundance of the trees and shrubs in the community, thereby leading to variations in the relative importance of seed versus establishment limitation. When human management increased densities of tree and/or shrub adults (i.e. Pinus spp. in refor- 
Table 3. Values of emergence and survival limitation (mean \pm standard deviation) for each studied species or functional group. None means that no seeds were collected in the seed traps and therefore we could not calculate limitation values. When mean values are shown without a standard deviation, seeds were collected only in one of the plots of the landscape unit. Different letters indicate significant differences among landscape units for each species and year combination (lack of a letter indicates insufficient data for analyses)

\begin{tabular}{|c|c|c|c|c|c|c|c|c|c|c|}
\hline & \multirow{2}{*}{$\begin{array}{l}\text { Landscape } \\
\text { unit }\end{array}$} & \multicolumn{5}{|c|}{ Tree species } & \multicolumn{2}{|c|}{ Functional groups of shrubs } & \multirow[b]{2}{*}{ All trees } & \multirow[b]{2}{*}{ All shrubs } \\
\hline & & P. sylvestris & $\begin{array}{l}T . \\
\text { baccata }\end{array}$ & $\begin{array}{l}P . \\
\text { nigra }\end{array}$ & $\begin{array}{l}\text { A. } \\
\text { granatense }\end{array}$ & S. aria & $\begin{array}{l}\text { Fleshy- } \\
\text { fruited } \\
\text { shrubs }\end{array}$ & $\begin{array}{l}\text { Dry-fruited } \\
\text { shrubs }\end{array}$ & & \\
\hline \multicolumn{11}{|c|}{ Emergence } \\
\hline \multicolumn{11}{|c|}{$\begin{array}{l}\text { limitation } \\
2004\end{array}$} \\
\hline & Native forest & $0.86 \pm 0.06^{\mathrm{a}}$ & 1 & None & $0.69 \pm 0.44^{\mathrm{a}}$ & $0.75 \pm 0.35^{\mathrm{a}}$ & $0.43 \pm 0.11^{\mathrm{a}}$ & $0.37 \pm 0.55^{\mathrm{a}}$ & $0.76 \pm 0.14^{\mathrm{a}}$ & $0.36 \pm 0.05^{\mathrm{ab}}$ \\
\hline & Reforestation & $0.35 \pm 0.35^{\mathrm{b}}$ & None & $1 \pm 0$ & 0 & $0.25 \pm 0.5^{\mathrm{a}}$ & $0.26 \pm 0.21^{\mathrm{b}}$ & $0.25 \pm 0.5^{\mathrm{a}}$ & $0.35 \pm 0.35^{\mathrm{b}}$ & $0.23 \pm 0.21^{\mathrm{a}}$ \\
\hline & Shrubland & $1 \pm 0^{\mathrm{a}}$ & 1 & $1 \pm 0$ & $0.83 \pm 0.24^{\mathrm{a}}$ & None & $0.25 \pm 0.14^{\mathrm{b}}$ & $0.8 \pm 0.14^{\mathrm{b}}$ & $0.96 \pm 0.07^{\mathrm{c}}$ & $0.42 \pm 0.13^{\mathrm{b}}$ \\
\hline & Native forest & $1 \pm 0$ & 1 & None & 1 & 0 & $0.97 \pm 0.05^{\mathrm{a}}$ & $1 \pm 0$ & $0.98 \pm 0.03$ & $0.97 \pm 0.05$ \\
\hline & Reforestation & $0.98 \pm 0.05$ & None & $1 \pm 0$ & None & None & $0.86 \pm 0.26^{\mathrm{b}}$ & 0 & $0.99 \pm 0.04$ & $0.82 \pm 0.26$ \\
\hline & Shrubland & $1 \pm 0$ & None & $1 \pm 0$ & $1 \pm 0$ & None & $0.87 \pm 0.23^{\mathrm{b}}$ & $0.97 \pm 0.05$ & $1 \pm 0$ & $0.91 \pm 0.15$ \\
\hline \multicolumn{11}{|l|}{$\begin{array}{l}\text { Survival } \\
\text { limitation } \\
2004\end{array}$} \\
\hline \multirow{6}{*}{2005} & Native forest & $0.94 \pm 0.10^{\mathrm{a}}$ & None & None & 0.38 & 1 & $0.47 \pm 0.3^{\mathrm{a}}$ & $0.57 \pm 0.10^{\mathrm{a}}$ & $0.77 \pm 0.27^{\mathrm{a}}$ & $0.45 \pm 0.28^{\mathrm{a}}$ \\
\hline & Reforestation & $0.96 \pm 0.10^{\mathrm{a}}$ & None & None & 1 & $0.33 \pm 0.58$ & $0.42 \pm 0.37^{\mathrm{ab}}$ & $0.60 \pm 0.53^{\mathrm{a}}$ & $0.94 \pm 0.09^{\mathrm{b}}$ & $0.41 \pm 0.4^{\mathrm{b}}$ \\
\hline & Shrubland & None & None & None & 0 & None & $0.14 \pm 0.03^{\mathrm{b}}$ & $0.39 \pm 0.35^{\mathrm{a}}$ & 0 & $0.19 \pm 0.1^{\mathrm{b}}$ \\
\hline & Native forest & None & None & None & None & 1 & 1 & None & 1 & 1 \\
\hline & Reforestation & 1 & None & None & None & None & $0.75 \pm 0.35$ & 1 & 1 & $0.83 \pm 0.29$ \\
\hline & Shrubland & None & None & None & None & None & 0.36 & 1 & None & 0.42 \\
\hline
\end{tabular}

estation stands; shrub species in shrubland), seed arrival was not a major limitation, but rather the existence of suitable microsites for seedling establishment was limiting. In contrast, when degradation implied a reduction in the number of adults as a consequence of fire, logging or light scarcity (i.e. all tree species in shrubland; shrub species in reforestation stands), recruitment was limited in terms of seed arrival as well as establishment. Therefore, we found a consistent spatial pattern of seed limitation that is inversely related to adult density, whereas establishment limitation was high in all landscape units. However, the magnitude of recruitment limitation depended on speciesspecific characteristics, such as biogeographical distribution, dispersal type and life form of each species, and was subject to strong inter-annual variability.

Species-specific variability of seed versus establishment limitation

\section{Biogeographical distribution}

The woody community in the study area was biogeographically diverse, including boreo-alpine species at the southern limit of their distribution ( $T$. baccata and $P$. sylvestris), sub-Mediterranean species with European-North African (S. aria) or Iberian-North African (A. granatense) distributions, and species with typical Mediterranean distribution and requirements ( $P$. nigra and all shrub species; Blanca et al. 2002). Boreo-alpine species were more recruitment-limited than the rest of the woody species, presumably because they suffer from suboptimal conditions under a Mediterranean climate that limit seedling emergence and survival (García et al. 2000; Castro et al. 2004). Establishment limitation of A. granatense, S. aria and shrubs (species with Mediterranean or sub-Mediterranean ecological requirements) was also high, but at least it was not completely precluded with regard to the rest of the species.

\section{Dispersal type}

The dispersal type influenced the spatial variation of seed versus establishment limitation and uncoupled it from adult abundance. Species with wind and ballistic dispersal followed the general spatial pattern of higher seed limitation at lower adult densities, because dispersal distances are shorter (mainly for ballistic dispersal) and therefore seed arrival depends on the proximity of parents (Castro et al. 2004; Gómez-Aparicio et al. 2007). Nevertheless, in both study years, we found dispersed A. granatense seeds in the shrubland, where parents were absent, indicating the existence of longdistance dispersal events for this species, which are vital for forest expansion (Nathan 2006). 
For species dispersed by animals, seed limitation was not necessarily lower in landscape units with higher adult density, but rather depended on frugivore patterns. For example, fleshy-fruited shrubs had the lowest seed limitation in the native forest, despite adult density being relatively low (especially when compared with shrubland). The native forest offers food and shelter to bird dispersers thanks to its high degree of structural heterogeneity (García et al. 2000). In addition, birds are important long-distance dispersers and their movements may also reduce differences in seed deposition among landscape units (García et al. 2005; Jordano et al. 2007). For this reason, we found seeds of zoochorous species in all landscape units, even when parents were absent or scarce (i.e. S. aria in the native forest).

\section{Life form}

The relative importance of the two components of recruitment limitation (seed versus establishment limitation) was consistent among life-form groups. Both the trees and the shrubs were, in general, more establishment- than seed-limited (Fig. 1). However, establishment limitation was stronger for trees than for shrubs, which recruited more seedlings in all landscape units. Despite the fact that dry-fruited shrubs are normally considered pioneer species (Blanca et al. 2002), they were less successful in recruitment than fleshy-fruited shrubs. In addition, seedlings surviving the second year were mainly those of fleshy-fruited shrubs $(81.6 \%)$.

Stronger establishment limitation for trees than shrubs indicates that two contrasting strategies suggested for maintenance of populations (regeneration and persistence; García \& Zamora 2003) may be operating in our communities. On the one hand, populations of fleshy-fruited shrub species seem to be maintained every year by regeneration (adults are replaced by seedlings), irrespective of climate conditions, as they were able to recruit in a very dry year. On the other hand, persistence by longevity is the maintenance strategy presumably operating in tree populations, particularly the more long-lived, mesic species such as T. baccata and P. sylvestris (García $\&$ Zamora 2003). Seedling recruitment in long-lived species would be successful only in exceptionally wet years that may occur only every 10 (or even every 100) years.

\section{Temporal variability of seed versus establishment limitation}

We found that temporal variability in rainfall overshadowed the spatial pattern of seedling estab- lishment. In 2004, a year of normal rainfall, establishment limitation was high in all landscape units but was not complete, as some species even showed intermediate limitation (i.e. fleshy-fruited shrubs in shrubland). In the very dry year (2005), recruitment almost completely collapsed: emergence was low, and very few of the emerged seedlings survived. As a result, the only species that were able to recruit in the dry year were fleshy-fruited shrubs. Moreover, as a persistent seed bank of woody species is non-existent in our study area, seeds dispersed in the dry year did not have the possibility of germinating in following years under more favourable climate conditions (Jiménez \& Armesto 1992).

Another source of temporal variability for recruitment was asynchronous fruit production dynamics (Kelly \& Sork 2002). Masting is a common pattern in Mediterranean plants (Herrera et al. 1998), and our results also confirmed inter-annual variability in fruit production (e.g. pine cone production for P. nigra), although all species produced fruits in both study years. Thus, the lack of recruitment in the very dry year might be a consequence of the scarcity of suitable microsites for establishment more than a lack of fruit production.

\section{Concluding Remarks}

Recruitment in both the normal and the very dry year was more successful for species with a Mediterranean distribution, zoochorous dispersal and shrubby life form, with fleshy-fruited shrubs being the only species that recruited in the very dry year. Furthermore, seedlings of fleshy-fruited shrubs are especially dominant in the two degraded landscape units: reforestation stand and shrubland. All these results indicate that all landscape units, irrespective of the degree of degradation, show potential development towards shrub dominance and arrested succession (Acácio et al. 2007). Because the current global climate scenario predicts harsher environmental conditions in the Mediterranean basin (increased frequency of extreme droughts, greater irregularity of precipitation and increased fire events for Mediterranean climate regions; Moreno 2005; IPCC 2007), native forests may be seriously threatened by the lack of recruitment of tree species. In a global change scenario, a rainy summer - the only suitable 'window of regeneration' for the more mesic species will become even rarer than today. These results therefore have strong implications for conservation, and even more so given that T. baccata, P. sylvestris, 
A. granatense and S. aria are listed as 'Vulnerable' by the IUCN (1994) and appear in the Red List of Threatened Vascular Plants of Andalusia (Blanca et al. 1998).

Acknowledgements. We thank Consejería de Medio Ambiente, Junta de Andalucía and the Director of Sierra Nevada National Park for fieldwork permissions. We are very grateful to Jorge Castro, Sergio de Haro, Asier Herrero, Ángel Navarra, José Luis Quero, Joaquín Sánchez and Nacho Villegas for field assistance, as well as Francisco Javier Bonet for plot size delimitation. Asier Herrero, Ramón Mendoza, Carolina Puerta-Piñero, José Luis Quero and two anonymous reviewers provided valuable comments on earlier drafts of this paper. David Nesbitt carefully reviewed the English in the paper. Financial support was provided by project MMA 24/ 2003, DINAMED CGL-2005-05830-CO3-03, FPU-MEC grant (2002-0626), contract Juan de la Cierva (2006-1342), and FPI-MEC grant (BES-2006-13562).

\section{References}

Anon. (IPCC) 2007. Climate change 2007. The physical science basis: working group I contribution to the fourth assessment report of the IPCC. Cambridge University Press, Cambridge, GB.

Anon. (IUCN) 1994. IUCN red list categories. IUCN, Gland.

Anon. (R Development Core Team) 2006. $R$ : a language and environment for statistical computing. $\mathrm{R}$ Foundation for Statistical Computing, Vienna, AT.

Acácio, V., Holmgren, M., Jansen, P.A. \& Schrotter, O. 2007. Multiple recruitment limitation causes arrested succession in Mediterranean cork oak systems. Ecosystems 10: 1220-1230.

Blanca, G., Cueto, M., Martinez-Lirola, M.J. \& MoleroMesa, J. 1998. Threatened vascular flora of Sierra Nevada (southern Spain). Biological Conservation 85: 269-285.

Blanca, G., López Onieva, M.R., Lorite, J., Martínez Lirola, M.J., Molero Mesa, J., Quintas, S., Ruiz, M., Varo, M.A. \& Vidal, S. 2002. Flora amenazada y endémica de Sierra Nevada. Ediciones Universidad de Granada, Granada, ES.

Blondel, J. 2006. The 'Design' of Mediterranean landscapes: a millennial story of humans and ecological systems during the historic period. Human Ecology 34: 713-729.

Castro, J., Zamora, R., Hódar, J.A. \& Gómez, J.M. 2004. Seedling establishment of a boreal tree species (Pinus sylvestris) at its southernmost distribution limit: consequences of being in a marginal Mediterranean habitat. Journal of Ecology 92: 266-277.

Castroviejo, S., Laínz, M., López González, G., Montserrat, P., Muñoz Garmendia, F., Paiva, J. \& Villar, L. 1986. Flora ibérica. Plantas vasculares de la
Península Ibérica e Islas Baleares. Real Jardín Botánico, C.S.I.C, Madrid, ES.

Clark, J.S., Macklin, E. \& Wood, L. 1998. Stages and spatial scales of recruitment limitation in southern Appalachian forests. Ecological Monographs 68: 213-235.

Clark, J.S., Beckage, B., Camill, P., Cleveland, B., HilleRisLambers, J., Lichter, J., McLachlan, J., Mohan, J. \& Wyckoff, P. 1999. Interpreting recruitment limitation in forests. American Journal of Botany 86: 1-16.

Conacher, A.J. \& Sala, M. (eds.). 1998. Land degradation in Mediterranean environments of the world. Nature and extent, causes and solutions. John Wiley, London, GB.

Dalling, J.W., Muller-Landau, H.C., Wright, S.J. \& Hubbell, S.P. 2002. Role of dispersal in the recruitment limitation of neotropical pioneer species. Journal of Ecology 90: 714-727.

Da Silva, J.M.C., Uhl, C. \& Murray, G. 1996. Plant succession, landscape management, and the ecology of frugivorous birds in abandoned Amazonian pastures. Conservation Biology 10: 491-503.

Eriksson, O. \& Ehrlén, J. 1992. Seed and microsite limitation of recruitment in plant populations. Oecologia 91: 360-364.

García, D. \& Zamora, R. 2003. Persistence, multiple demographic strategies and conservation in long-lived Mediterranean plants. Journal of Vegetation Science 14: 921-926.

García, D., Zamora, R., Hódar, J.A., Gómez, J.M. \& Castro, J. 2000. Yew (Taxus baccata L.) regeneration is facilitated by fleshy-fruited shrubs in Mediterranean environments. Biological Conservation 95: 31-38.

García, D., Obeso, J.R. \& Martínez, I. 2005. Spatial concordance between seed rain and seedling establishment in bird-dispersed trees: does scale matter? Journal of Ecology 93: 693-704.

Ghazoul, J., Liston, K.A. \& Boyle, T.J.B. 1998. Disturbance-induced density-dependent seed set in Shorea siamensis (Dipterocarpaceae), a tropical forest tree. Journal of Ecology 86: 462-473.

Gómez, J.M. 2003. Spatial patterns in long-distance dispersal of Quercus ilex acorns by jays in a heterogeneous landscape. Ecography 26: 573-584.

Gómez-Aparicio, L., Gómez, J.M. \& Zamora, R. 2007. Spatiotemporal patterns of seed dispersal in a winddispersed Mediterranean tree (Acer opalus subsp granatense): implications for regeneration. Ecography 30: $13-22$.

Hampe, A. \& Arroyo, J. 2002. Recruitment and regeneration in populations of an endangered South Iberian Tertiary relict tree. Biological Conservation 107: 263-271.

Herrera, C.M., Jordano, P., Guitián, J. \& Traveset, A. 1998. Annual variability in seed production by woody plants and the masting concept: reassessment of principles and relationship to pollination and seed dispersal. American Naturalist 152: 576-594. 
Jiménez, H.E. \& Armesto, J.J. 1992. Importance of the soil seed bank of disturbed sites in Chilean Matorral in early secondary succession. Joumal of Vegetation Science 3: 579-586.

Jordano, P. \& Herrera, C.M. 1995. Shuffling the offspring uncoupling and spatial discordance of multiple stages in vertebrate seed dispersal. Ecoscience 2: 230-237.

Jordano, P., Pulido, F., Arroyo, J., García-Castaño, J.L. \& García-Fayos, P. 2004. Procesos de limitación demográfica. In: Valladares, F. (ed.) Ecología del Bosque Mediterráneo en un mundo cambiante. pp. 229-248. Ministerio de Medio Ambiente de España, Organismo Autónomo de Parques Nacionales, Madrid, ES.

Jordano, P., García, C., Godoy, J.A. \& García-Castaño, J.L. 2007. Differential contribution of frugivores to complex seed dispersal patterns. Proceedings of the National Academy of Sciences of the United States of America 104: 3278-3282.

Kelly, D. \& Sork, V.L. 2002. Mast seeding in perennial plants: why, how, where? Annual Review of Ecology and Systematics 33: 427-447.

Mendoza, I. 2008. Regeneración de la biodiversidad de especies leñosas en un marco de degradación de hábitats mediterráneos de montaña: combinación de interacciones ecológicas y manejo humano. Ph Dissertation. University of Granada, Granada, ES.

Moreno, J.M. 2005. Principales conclusiones de la Evaluación Preliminar de los Impactos en España por efecto del Cambio Climático. Ministerio de Medio Ambiente, Madrid, Spain.

Muller-Landau, H.C., Wright, S.J., Calderón, O., Hubbell, S.P. \& Foster, R.B. 2002. Assessing recruitment limitation: concepts, methods and case studies from a tropical forest. In: Levey, D.J., Silva, W.R. \& Galetti, M. (eds.) Seed dispersal and frugivory: ecology, evolution and conservation. pp. 35-54. CAB International, Wallingford, GB.

Münzbergová, Z. \& Herben, T. 2005. Seed, dispersal, microsite, habitat and recruitment limitation: identification of terms and concepts in studies of limitations. Oecologia 145: 1-8.

Nathan, R. 2006. Long-distance dispersal of plants. Science 313: 786-788.

Nathan, R. \& Muller-Landau, H.C. 2000. Spatial patterns of seed dispersal, their determinants and consequences for recruitment. Trends in Ecology \& Evolution 15: 278-285.

Plieninger, T., Pulido, F.J. \& Konold, W. 2003. Effects of land-use history on size structure of holm oak stands in Spanish dehesas: implications for conservation and restoration. Environmental Conservation 30: 61-70.

Pulido, F.J. \& Díaz, M. 2005. Regeneration of a Mediterranean oak: a whole-cycle approach. Ecoscience 12: 92-102.

Rey, P.J., Ramírez, J.M. \& Sánchez-Lafuente, A.M. 2006. Seed- vs. microsite-limited recruitment in a myrmecochorous herb. Plant Ecology 184: 213-222.
Sanderson, E.W., Jaiteh, M., Levy, M.A., Redford, K.H., Wannebo, A.V. \& Woolmer, G. 2002. The human footprint and the last of the wild. Bioscience 52: 891-904.

Saracco, J.F., Collazo, J.A. \& Groom, M.J. 2004. How do frugivores track resources? Insights from spatial analyses of bird foraging in a tropical forest. Oecologia 139: 235-245.

Schupp, E.W. \& Fuentes, M. 1995. Spatial patterns of seed dispersal and the unification of plant population ecology. Ecoscience 2: 267-275.

Svenning, J.C. \& Wright, S.J. 2005. Seed limitation in a Panamanian forest. Journal of Ecology 93: 853-862.

Traveset, A., Gulias, J., Riera, N. \& Mus, M. 2003. Transition probabilities from pollination to establishment in a rare dioecious shrub species (Rhamnus ludovici-salvatoris) in two habitats. Journal of Ecology 91: 427-437.

Turnbull, L.A., Crawley, M.J. \& Rees, M. 2000. Are plant populations seed-limited? A review of seed sowing experiments. Oikos 88: 225-238.

Valdés, B., Talavera, S. \& Fernández-Galiano, E. 1987. Flora vascular de Andalucia occidental. Ketres, Barcelona, ES. 